\title{
Perfluorinated Compounds in Aquatic Organisms at Various Trophic Levels in a Great Lakes Food Chain
}

\author{
Kurunthachalam Kannan, ${ }^{1}$ Lin Tao, ${ }^{1}$ Ewan Sinclair, ${ }^{1}$ Stephanie D. Pastva, ${ }^{2}$ Dave J. Jude, ${ }^{3}$ John P. Giesy ${ }^{2,4}$ \\ ${ }^{1}$ Wadsworth Center, New York State Department of Health and Department of Environmental Health and Toxicology, School of Public Health, State \\ University of New York at Albany, Empire State Plaza, PO Box 509, Albany, New York 12201-0509, USA \\ ${ }^{2}$ National Food Safety and Toxicology Center, Department of Zoology, Center for Integrative Toxicology, Michigan State University, East Lansing, \\ Michigan 48824-1311, USA \\ ${ }^{3}$ School of Natural Resources and the Environment, University of Michigan, 501 East University, Ann Arbor, Michigan, USA \\ ${ }^{4}$ Department of Biology and Chemistry, City University of Hong Kong, Kowloon, Hong Kong
}

Received: 15 June 2004/Accepted: 20 August 2004

\begin{abstract}
Trophic transfer of perfluorooctanesulfonate (PFOS) and other related perfluorinated compounds was examined in a Great Lakes benthic foodweb including wateralgae-zebra mussel-round goby-smallmouth bass. In addition, perfluorinated compounds were measured in livers and eggs of Chinook salmon and lake whitefish, in muscle tissue of carp, and in eggs of brown trout collected from Michigan. Similarly, green frog livers, snapping turtle plasma, mink livers, and bald eagle tissues were analyzed to determine concentrations in higher trophic-level organisms in the food chain. PFOS was the most widely detected compound in benthic organisms at various trophic levels. Concentrations of PFOS in benthic invertebrates such as amphipods and zebra mussels were approximately 1000 -fold greater than those in surrounding water, which suggested a bioconcentration factor (BCF; concentration in biota/concentration in water) of 1000 in benthic invertebrates. Concentrations of PFOS in round gobies were two- to fourfold greater than those in their prey organisms such as zebra mussels and amphipods. Concentrations of PFOS in predatory fishes (Chinook salmon and lake whitefish) were 10 to 20-fold greater than those in their prey species. Concentrations of PFOS in mink and bald eagles were, on average, 5to 10-fold greater than those in Chinook salmon, carp, or snapping turtles. Because of the accumulation of PFOS in liver and blood, the biomagnification factor (BMF) of perfluorinated compounds in higher trophic-level organisms such as salmonid fishes, mink, and eagles were based on the concentrations in livers or plasma. Overall, these results suggest a BCF of PFOS of approximately 1000 (whole-body based) in benthic invertebrates, and a BMF of 10 to 20 in mink or bald eagles, relative to their prey items. Eggs of fish contained notable concentrations of PFOS, suggesting oviparous transfer
\end{abstract}

Correspondence to: Kurunthachalam Kannan; email: kkannan@ wadsworth.org of this compound. PFOA was found in water, but its biomagnification potential was lower than that of PFOS.

Perfluorooctane sulfonate (PFOS), a fluorinated organic contaminant, has been the subject of many recent investigations (Hansen et al. 2001; Kannan et al. 2001a,b; Kannan et al. 2002a,b,c,d; Moody et al. 2002; Van de Vijver et al. 2003; Martin et al. 2004; Stock et al. 2004). Widespread distribution of PFOS in wildlife tissues collected from several regions of the globe has been reported (Giesy and Kannan 2001, 2002; Martin et al. 2004). Additional perfluorinated organic contaminants, such as perfluorohexanesulfonate (PFHS), perfluorooctanoate (PFOA), and perfluorooctanesulfonamide (PFOSA) have been reported to occur in the environment, although at lower concentrations and frequencies than PFOS. Earlier studies have suggested that concentrations of PFOS tend to be higher in predatory organisms than in lower trophic-level organisms of aquatic food chains (Kannan et al. 2002c). For instance, fisheating birds (e.g., bald eagles) and mammals (e.g., mink) contained some of the highest concentrations of PFOS reported thus far. Nevertheless, earlier studies measuring concentrations of PFOS in biota have focused primarily on higher trophic-level organisms. Studies reporting the occurrence of PFOS in aquatic organisms at lower trophic levels in a food chain are scanty. In order to determine the biomagnification potential of PFOS in aquatic food webs, we need to measure concentrations in organisms at various trophic levels. In this study, we have measured concentrations of PFOS, PFHS, PFOA, and PFOSA in water, benthic algae, amphipods, zebra mussel (Dreissena polymorpha), crayfish, round gobies (Neogobius melanostomus), and smallmouth bass (Micropterus dolomieui) collected from three riverine locations. This represents a characteristic benthic food chain of the Great Lakes since the invasion of the Great Lakes by zebra mussels in the late 1980s; and by round gobies in the early 1990s (Hanari et al. 2004). 


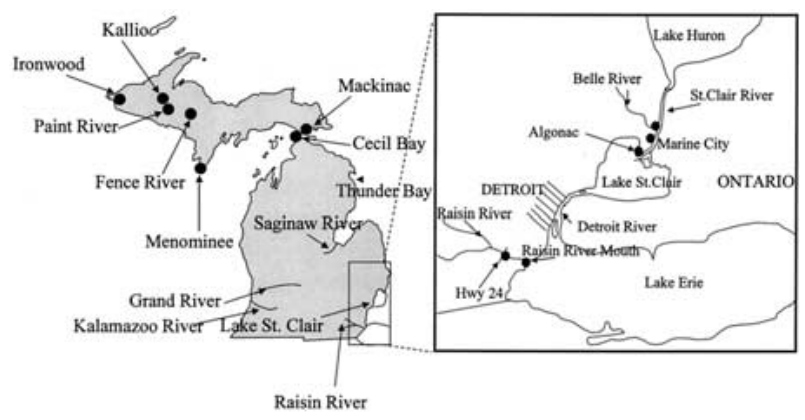

Fig. 1. Map of Michigan showing sampling locations.

Analysis of perfluorochemical concentrations in wateralgae-zebra mussels-round gobies-smallmouth bass - can provide information on the food-chain transfer of these compounds to higher trophic-level organisms. Zebra mussels can sequester contaminants by ingesting algae and other suspended materials, or directly from water (Bruner et al. 1994). Round gobies generally eat zebra mussels ranging in size from 3 to $12 \mathrm{~mm}$ (Jude et al. 1995). In particular, small round gobies ( $<50 \mathrm{~mm}$ standard length) feed primarily on benthic arthropods such as amphipods, whereas the diet of larger gobies is composed primarily of zebra mussels. In addition, crayfish have been found to consume zebra mussels in laboratory studies (Martin and Corkum 1994). Round gobies are prey species for several game fish species, including smallmouth bass and brown trout (Salmo trutta). Smallmouth bass from Calumet Harbor, the St. Clair River, and western Lake Erie have been shown to prey on round gobies (Savitz et al. 1996).

In addition to the benthic invertebrates and forage fish species, tissues of Chinook salmon (Oncorhynchus tshawytscha), lake whitefish (Coregonus clupeaformis), brown trout, carp (Cyprinus carpio), green frogs (Rana clamitans), snapping turtles (Chelydra serpentina), bald eagles (Haliaeetus leucocephalus), and mink (Mustela vison) collected from various locations in Michigan were also analyzed for determination of the concentrations of perfluorinated compounds in higher trophic-level organisms of the Great Lakes food chain. Mink are carnivores and primarily feed on small mammals, birds, frogs, crayfish, fish, lizards, small snakes, and insects. The bald eagle's diet consists of fish, turtles, waterbirds such as ducks, small mammals such as muskrats, and snakes. Snapping turtles eat algae, aquatic insects, small fish, frogs, snails, and young waterfowl.

\section{Materials and Methods}

\section{Sampling}

Biotic samples were collected from several rivers in Michigan and in the Calumet River in Indiana, USA, during 1998-2001. The sampling locations are shown in Figure 1. Benthic algae, amphipods, zebra mussels, crayfish, round gobies, and smallmouth bass were collected from various locations within $1 \mathrm{~km}$ of the Raisin River mouth to Lake Erie, and from the St. Clair River at its confluence with the Belle River, at Marine City, and at Algonac, Michigan. The benthic organisms were also collected from the Calumet River at its confluence with Lake Michigan in Indiana. All of the biotic samples were collected during July to November, 1998 and 1999. Water samples were collected from the St. Clair and Raisin Rivers in 2001 at the locations where benthic organisms had been collected. No water samples were collected from the Calumet River.

Several hundred zebra mussels were collected from rocky substrata at each location by snorkeling or scuba diving. Fishes were collected by seining or by electroshocking. Amphipods were collected by turning over rocks and using forceps to collect individual organisms. Benthic algae were collected by scraping hard surfaces with a clean toothbrush (for nonfilamentous forms), or by hand-picking tufts of filamentous algae. Skinless fillets were analyzed for smallmouth bass, whereas the whole body was analyzed for round gobies. Soft tissues of zebra mussels were analyzed. Tissues from several individuals per species (including fish) were pooled to obtain an adequate mass for extraction. Length of each individual fish was measured immediately after collection, and individuals were pooled on the basis of sizes for analysis (Table 1).

A few higher trophic-level fishes such as Chinook salmon, lake whitefish, brown trout, and carp were also collected from Michigan waters in 1999 and 2000. Liver and egg samples were obtained from these fishes for analysis. Muscle tissue was analyzed for carp. Plasma from snapping turtles collected from Macomb County, along Lake St. Clair, in June 1999, was analyzed. All of the turtles were adults. A large mass of eggs was found in all female turtles. Livers from adult green frogs collected in 1998 from the vicinity of Calkins Dam on the Kalamazoo River in southwestern Michigan were analyzed. Livers were analyzed from mink collected by trappers from the Kalamazoo River watershed in 2000-2001.

Carcasses of bald eagles that were found dead in the Upper Peninsula of Michigan in 2000 were collected by or submitted to Rose Lake Wildlife Research Center, Lansing, Michigan. The carcasses were transported to the wildlife research center and, upon receipt, they were necropsied and the cause of death was determined. Samples of liver, muscle, fat, kidney, and gallbladder (from nondecomposed carcasses) were wrapped in solvent-cleaned aluminum foil and stored at $-20^{\circ} \mathrm{C}$ until analysis. The gallbladder was filled with bile when collected.

\section{Chemical Analysis}

Tissue samples of fish, mussel, amphipods, and algae were analyzed by a solid-phase extraction (SPE) method. Approximately $1 \mathrm{~g}$ of sample was cut into small pieces, and $5 \mathrm{~mL}$ of Milli-Q water was added. Samples were then ground using an Ultra-Turrax tissue homogenizer. To $1 \mathrm{~mL}$ of the extract taken in a polypropylene tube, $5 \mathrm{~mL}$ of acetonitrile was added; the tube was shaken for $20 \mathrm{~min}$. The homogenate was then centrifuged at $2000 \mathrm{rpm}$ for $10 \mathrm{~min}$. The supernatant (acetonitrile layer) was decanted into a polypropylene tube containing 40 $\mathrm{mL}$ of Milli-Q water. PFOS, PFOSA, PFOA, and PFHS were extracted from the samples using C18 SPE extraction cartridges ( $1 \mathrm{~g}$, Sep-Pak $6 \mathrm{cc}$ tri-functional $\mathrm{C}_{18}$; Waters, Milford, MA). Sample flow rate was maintained at $5-7 \mathrm{~mL} / \mathrm{min}$. SPE cartridges were conditioned by washing twice with approximately $5 \mathrm{~mL}$ of methanol, followed by approximately two 5-mL aliquots of water; care was taken not to allow the column to run to dryness after each wash. After conditioning, samples were passed through the cartridge, which was then allowed to dry. Cartridges were then eluted with $0.5 \mathrm{~mL}$ methanol.

Bald eagle liver, kidney, muscle, testes, ovaries, and gallbladder were analyzed using an ion-pair extraction method described elsewhere (Hansen et al. 2001; Kannan et al. 2001a). Similarly, livers and eggs of Chinook salmon and lake whitefish, muscle tissue of carp, eggs of brown trout, livers of frog and mink, and plasma of snapping 
Table 1. Concentrations of PFOS, PFOSA, PFOA, and PFHS in water (ng/L) and benthic organisms (ng/g, wet weight) of a Great Lakes food chain

\begin{tabular}{|c|c|c|c|c|c|c|}
\hline Location & Species/specimen & PFOS & PFOSA & PFOA & PFHS & Remarks (size, date) \\
\hline \multirow[t]{17}{*}{ Raisin River } & Water (ng/L) & 3.5 & $<10$ & 14.7 & $<1$ & Near Monroe, Mar 2001 \\
\hline & Benthic algae & 2.4 & $<1$ & $<0.2$ & $<2$ & Near Ford Plant, Sept 99 \\
\hline & Amphipods & 2.9 & $<2$ & $<5$ & $<1$ & Near Ford Plant, Sept 99 \\
\hline & \multirow[t]{2}{*}{ Zebra mussel } & 3.1 & 2.7 & $<5$ & $<1$ & $8-20 \mathrm{~mm}$, Oct 98 \\
\hline & & $<2$ & 3.8 & $<5$ & $<1$ & 10-19 mm, Aug 99 \\
\hline & Crayfish & 4.3 & 1.6 & $<0.2$ & $<2$ & Sep 99, 61-66 mm \\
\hline & \multirow[t]{3}{*}{ Round gobies } & 11.2 & 1.6 & $<0.2$ & $<2$ & Near Edison, 70-96 mm, Sept 99 \\
\hline & & 7.2 & 2.1 & $<2$ & $<1$ & $77-87 \mathrm{~mm}$, Oct 98 \\
\hline & & 6.6 & 1.8 & $<0.2$ & $<2$ & Port of Monroe, $95-109 \mathrm{~mm}$, Oct 98 \\
\hline & \multirow[t]{8}{*}{ Smallmouth bass } & 41.3 & 2.7 & $<2$ & $<1$ & 56-98 mm, Sept 98 \\
\hline & & 2.0 & 1.2 & $<2$ & $<1$ & 69-146 mm, Sept 99 \\
\hline & & 3.6 & 1.4 & $<2$ & $<1$ & 174-210 mm, Sept 98 \\
\hline & & 5.8 & 1.8 & $<2$ & $<1$ & 250-257 mm, Sept 99 \\
\hline & & 7.6 & 2.4 & $<2$ & $<1$ & 256-314 mm, Sept 98 \\
\hline & & 19.8 & 4.1 & $<2$ & $<1$ & $343-406 \mathrm{~mm}$, Sept 98 \\
\hline & & 8.6 & 1.2 & $<2$ & $<1$ & 349-357 mm, Sept 99 \\
\hline & & 17.8 & $<1$ & $<2$ & $<1$ & 414-416 mm, Sept 99 \\
\hline \multirow[t]{15}{*}{ St. Clair River } & Water (ng/L) (n = 3) & $2.6(1.9-3.9)$ & $<10$ & $4.4(4.0-5.0)$ & $<1$ & Apr 2001 \\
\hline & Benthic algae & 2.6 & $<1$ & $<0.2$ & $<2$ & Marine City, July 99 \\
\hline & Amphipods & $<2$ & $<2$ & $<5$ & $<1$ & Marine City, Sept 99 \\
\hline & Zebra mussel & $<2$ & $<2$ & $<5$ & $<1$ & Marine City, 12-24 mm, Nov 98 \\
\hline & Crayfish & 2.4 & 1.4 & $<0.2$ & $<2$ & Marine City, 40-75 mm, Sept 99 \\
\hline & \multirow[t]{8}{*}{ Round gobies } & 19.1 & 3.4 & $<0.2$ & $<2$ & Marine City, 77-82 mm, July 99 \\
\hline & & 7.7 & 1 & $<0.2$ & $<2$ & Belle River, 77-83 mm, Sept 98 \\
\hline & & 9.6 & 1.8 & $<0.2$ & $<2$ & Marine City, 82-102 mm, July 99 \\
\hline & & 14.9 & 1.8 & $<0.2$ & $<2$ & Belle River, 88-102 mm, Sept 98 \\
\hline & & 8.9 & 1.9 & $<0.2$ & $<2$ & Belle River, 112-120 mm, Sept 98 \\
\hline & & 21.5 & 5.2 & $<0.2$ & $<2$ & St.Clair River, 122-140 mm, Sept 99 \\
\hline & & 8.7 & $<1$ & $<0.2$ & $<2$ & Marine City, 128-133 mm, July 99 \\
\hline & & 7.7 & 1.1 & $<0.2$ & $<2$ & Belle River, $159 \mathrm{~mm}$, Sept 98 \\
\hline & \multirow[t]{2}{*}{ Smallmouth bass } & $<2$ & 6.3 & $<2$ & $<1$ & 174-203 mm, Aug 99 \\
\hline & & 2.7 & 1.1 & $<2$ & $<1$ & $312-368 \mathrm{~mm}$, Oct 98 \\
\hline \multicolumn{7}{|l|}{ Calumet River } \\
\hline & Benthic algae & 3.1 & $<1$ & $<0.2$ & $<2$ & Calumet Harbor, July 99 \\
\hline & Amphipods & $<2$ & $<2$ & $<5$ & $<1$ & Calumet Harbor, July 99 \\
\hline & \multirow[t]{3}{*}{ Zebra mussel } & $<2$ & $<2$ & $<5$ & $<1$ & 5-23 mm, Sept 98 \\
\hline & & $<2$ & $<2$ & $<5$ & $<1$ & $8-21 \mathrm{~mm}$, Sept 98 \\
\hline & & $<2$ & $<2$ & $<5$ & $<1$ & 10-21 mm, July 99 \\
\hline & Crayfish & 3.7 & $<1$ & $<0.2$ & $<2$ & Calumet Harbor, 81-100 mm, July 99 \\
\hline & Round gobies & 4.1 & $<1$ & $<0.2$ & $<2$ & Calumet Harbor, 77-92 mm, July 99 \\
\hline & \multirow[t]{4}{*}{ Smallmouth bass } & 5.1 & $<1$ & $<0.2$ & $<2$ & Calumet park, 256-314 mm, May 98 \\
\hline & & 7.6 & $<1$ & $<2$ & $<1$ & Calumet Harbor, $335-355 \mathrm{~mm}$, Aug 99 \\
\hline & & 2.5 & $<1$ & $<2$ & $<1$ & 380-390 mm, May 98 \\
\hline & & 2.6 & $<1$ & $<2$ & $<1$ & 415-425 mm, May 98 \\
\hline
\end{tabular}

PFOS = perfluorooctanesulfonate; PFOSA = perfluorooctane sulfonamide;

PFOA = perfluorooctanoate; PFHS = perfluorohexanesulfonate.

turtles were analyzed by the ion-pair extraction method. Briefly, homogenates of the tissue matrices were prepared in $5 \mathrm{~mL}$ of water. One milliliter of $0.5 \mathrm{M}$ tetrabutylammonium hydrogen sulfate solution and $2 \mathrm{~mL}$ of sodium carbonate buffer $(0.25 \mathrm{M}, \mathrm{pH} 10)$ were added to $1 \mathrm{~mL}$ of plasma or tissue homogenate in a polypropylene tube, and the tube was thoroughly mixed for extraction. Five milliliters of methyl-tertbutyl ether (MTBE) was added to the above mixture and shaken for 20 min. After centrifugation, the MTBE layer was transferred into another polypropylene tube. The solvent was evaporated under nitrogen and replaced with $1 \mathrm{~mL}$ of methanol. This extract was passed through a nylon mesh filter $(0.2 \mu \mathrm{m})$ into an HPLC vial.

Water samples were analyzed following the SPE method described elsewhere (Yamashita et al. 2004). Water samples were allowed to settle, and particulate matter was kept to a minimum for extraction.
Briefly, a sample aliquot of water $(100 \mathrm{~mL})$ was passed through the preconditioned Oasis ${ }^{\circledR}$ HLB $(60 \mathrm{mg}, 3 \mathrm{cc}$ ) cartridges (Waters Corporation, Milford, MA) at a rate of $1 \mathrm{drop} / \mathrm{sec}$. The cartridges were not allowed to dry out prior to passing water samples. The cartridges were then washed with $1 \mathrm{~mL}$ of $40 \%$ methanol in water, which was discarded. The target analytes were eluted with $5 \mathrm{~mL}$ of methanol, and were collected in a polypropylene tube. The solvent was evaporated under a gentle stream of pure nitrogen to $1 \mathrm{~mL}$ for HPLC-MS/MS analysis. Particles that appeared in the final solution of a few of the water samples were removed by filtration using a nylon syringe filter.

Quantitative analyses were performed by monitoring a single product ion selected from a primary ion characteristic of a particular fluorochemical using HPLC-ES/MS/MS. For example, molecular ion $\mathrm{m} / \mathrm{z}=499$, selected as the primary ion for PFOS $\left(\mathrm{C}_{8} \mathrm{~F}_{17} \mathrm{SO}_{3}{ }^{-}\right)$anal- 
ysis, was fragmented further to produce ion $\mathrm{m} / \mathrm{z}=99\left(\mathrm{FSO}_{3}{ }^{-}\right)$. The characteristic product ion $(\mathrm{m} / \mathrm{z}=99)$ was monitored for quantitative analysis. Quantitation of the target analytes was based on quadratic regression fit analysis weighted $1 / \mathrm{x}$ of a single unextracted curve for each group of tissue samples. High or low points on the curve were deactivated, if necessary, to provide a better linear fit over the curve range most appropriate to samples. Low points on the curve with peak areas less than that of the average response from the procedural blanks were deactivated, to disqualify a data range that may have been significantly affected by background levels of the analyte. Quantitation of each analyte was based on the response of one specific product ion using the multiple reaction-monitoring (MRM) mode of the instrument. Unextracted calibration standards were prepared at approximately $0.10 \mathrm{ng} / \mathrm{mL}-750 \mathrm{ng} / \mathrm{mL}$ for analysis. The coefficient of determination $\left(\mathrm{r}^{2}\right)$ of each standard curve was $>0.99$.

Specificity for analyte identification was demonstrated by chromatographic retention time and mass spectral daughter ion characterization. Additional confirmatory tests were performed for PFOS. In the electrospray tandem mass spectrometry (ES/MS/MS) system, the $499 \mathrm{Da} \rightarrow 80 \mathrm{Da}$ transition can provide a stronger signal than the $499 \mathrm{Da} \rightarrow 99 \mathrm{Da}$ transition of the PFOS analysis. However, in the analysis of tissue samples collected from some species, an unidentified interferent may be present in the $499 \mathrm{Da} \rightarrow 80 \mathrm{Da}$ transition. Although this interferent is rarely observed, quantitation was based on the $499 \mathrm{Da} \rightarrow 99 \mathrm{Da}$ transition to ensure complete selectivity. To confirm the identity of PFOS in samples containing $>70 \mathrm{ng} / \mathrm{g}$ (>10 ng/ $\mathrm{mL}$ ), at least two transitions were monitored and were required to show quantitative agreement to within $\pm 30 \%$. Typically, $499>99$ and $499>80$ transitions were monitored. On the occasions when these two transitions differed by more than $30 \%$, the sample was reanalyzed by monitoring for the $499>80,499>99$, and $499>130$ transitions. If the $499>130$ and $499>99$ transitions showed quantitative agreement to within $\pm 30 \%$, the PFOS concentration was considered confirmed.

A well-characterized matrix of rabbit liver was used as surrogate tissue for matrix blanks. All water blank peak areas were less than or equal to half the peak area of the limit of quantitation (LOQ) for the compounds of interest. The LOQ is equal to the lowest acceptable standard in the calibration curve (defined as a standard within $\pm 30 \%$ of the theoretical value), and has a peak area two times greater than the analyte peak area detected in the average of the water blanks. Because low levels of the target analytes are ubiquitous in the laboratory, it is imperative that these criteria for LOQ determination be observed. The LOQs for perfluorinated compounds in biological matrices analyzed using the SPE method ranged from 1 to $10 \mathrm{ng} / \mathrm{g}$, wet wt. The LOQs for the samples analyzed using the ion-pair extraction method ranged from 7.5 to $75 \mathrm{ng} / \mathrm{g}$, wet wt. Fluoropolymercontaining vial caps and sample containers were avoided.

Several matrix spikes were prepared for tissue samples. These tissues were spiked with target compounds at levels of 1, 1.4, 3, 4, 10, and $14 \mathrm{ng} / \mathrm{g}$ for amphipod, zebra mussel, benthic algae, crayfish, round gobies, and smallmouth bass muscle, respectively, and were passed through the whole analytical procedure. Mink livers were spiked at $600 \mathrm{ng} / \mathrm{g}$ level. Recoveries of PFOS ranged from $67 \%$ in benthic algae to $136 \%$ in bass muscle. Recoveries of PFHS varied from $65 \%$ to $140 \%$. Recoveries of PFOSA and PFOA were less than $50 \%$ in most cases and varied widely. Therefore, the reported values for PFOSA and PFOA are considered semiquantitative. The reported concentrations were not corrected for recoveries. The measurement of accuracy available at this time, matrix spike studies, indicates that the data for water, benthic algae, amphipods, zebra mussel, crayfish, round gobies, and smallmouth bass are within $\pm 50 \%$ for PFOS and PFHS. PFOS data for Chinook salmon, lake whitefish, brown trout, carp, snapping turtle, frog, mink, and bald eagle tissues should be considered accurate within $\pm 30 \%$. Because of the variations in recoveries and accuracy of PFOS analysis, a biomagnification factor (BMF) of 2 or less should be considered insignificant.

\section{Results and Discussion}

PFOS was the most commonly detected fluoroorganic compound in various organisms of the Great Lakes food chain examined (Table 1). PFOS and PFOA were found in water samples from all of the locations, at mean concentrations of 2.6-17 and 4.4-22 ng/L, respectively. Concentrations of PFOS in water samples were within the range of $<0.8-30 \mathrm{ng} / \mathrm{L}$, reported for several Michigan surface waters (Sinclair et al. 2004). Concentrations of PFOA were slightly higher than those of PFOS in water samples. The measured concentrations of PFOS and PFOA were similar to those reported for inland and coastal waters of Japan (Taniyasu et al. 2003; Saito et al. 2003), but severalfold lower than those reported for areas impacted by local sources of contamination (Schultz et al. 2004; Hansen et al. 2002; Moody et al. 2002).

Concentrations of PFOS in lower trophic-level organisms in the food chain are on the order of a few nanograms per gram (ppb). This is approximately three orders of magnitude greater than the concentrations found in surface waters. For example, the concentration of PFOS in a water sample from the Raisin River was $3.5 \mathrm{ng} / \mathrm{L}$, whereas that in benthic algae, amphipods, and zebra mussels was in the range of $2.4-3.1 \mathrm{ng} / \mathrm{g}$, wet weight. This suggests a bioconcentration factor (BCF) of PFOS of approximately 1000 . Based on the water concentration of $3.5 \mathrm{ng} / \mathrm{L}$ and a whole-body PFOS concentration in round gobies of $8.3 \mathrm{ng} / \mathrm{g}$, wet weight, a BCF of 2400 was calculated. This value is within the range reported for lake trout exposed to PFOS under laboratory conditions (Martin et al. 2003). BCFs of PFOS were reported to be 1100 in carcass and 5400 in liver of rainbow trout exposed under laboratory conditions (Martin et al. 2003). Despite the occurrence of PFOA in water samples, this compound was not found in the tissues of any of the benthic organisms analyzed at a LOQ of $0.2-2 \mathrm{ng} / \mathrm{g}$. This may be due to a low bioconcentration potential of PFOA. The BCF reported for PFOA in rainbow trout exposed under laboratory conditions ranged between 4 and 27; this range is 1000-fold lower than that reported for PFOS (Martin et al. 2003).

In general, concentrations of perfluorinated compounds were low in lower trophic-level organisms such as amphipods and zebra mussels (e.g., <2-4.3 ng/g, wet weight) and relatively higher in round gobies and smallmouth bass (e.g., $2-41.3 \mathrm{ng} / \mathrm{g}$, wet weight). Mean concentrations of PFOS in round gobies and smallmouth bass from the Raisin River were 8.3 and $13.3 \mathrm{ng} / \mathrm{g}$, wet weight, respectively. The concentrations of PFOS in round gobies and smallmouth bass were twoto fourfold higher than those found in benthic algae and crayfish, suggesting a BMF of two to four between algae/ crayfish and round gobies. However, no marked variation was noted for the concentrations of PFOS among the three benthic organisms analyzed; algae, amphipods, and zebra mussels. Similarly, concentrations of PFOS were not significantly different among the three locations investigated. No size-related differences in the concentrations of PFOS in round gobies or smallmouth bass could be discerned. The mean concentration of PFOS in round gobies from the St. Clair River was $12.3 \mathrm{ng} /$ $\mathrm{g}$, wet weight, which was greater than the concentrations found in smallmouth bass collected from the same location. Similarly, concentrations of PFOS in round gobies and in small- 
Table 2. Concentrations of PFOS, PFOSA, PFOA, and PFHS (ng/g, wet wt) in fish from Michigan waters, USA

\begin{tabular}{|c|c|c|c|c|c|c|}
\hline Species & Tissue & Location & PFOS & PFOSA & PFOA & PFHS \\
\hline Chinook salmon $(n=6)$ & Liver & Webber Dam, Grand River & $100(32-173)$ & $<19$ & $<72$ & $<17$ \\
\hline Lake whitefish $(\mathrm{n}=5)$ & Liver & Thunder Bay, Lake Huron & $67(33-81)$ & $<19$ & $<72$ & $<17$ \\
\hline Lake whitefish $(\mathrm{n}=2)$ & Eggs & Thunder Bay, Lake Huron & $263(145-381)$ & $<19$ & $<36$ & $<34$ \\
\hline Brown trout $(n=3)$ & Eggs & Marquette, Lake Superior & $64(49-75)$ & $<19$ & $<18$ & $<34$ \\
\hline $\operatorname{Carp}(n=10)$ & Muscle & Saginaw Bay & $124(59-297)$ & $<19$ & $<36$ & $<34$ \\
\hline
\end{tabular}

Notes: Values below LOQ are denoted by '<'; Values below the detection limit were not included in the estimation of mean (in parentheses). For abbreviation, see Table 1.

Table 3. Concentrations of PFOS, PFOSA, PFOA, and PFHS (ng/g, wet wt) in livers of mink and green frog collected from Kalamazoo, and in plasma $(\mathrm{ng} / \mathrm{mL})$ of snapping turtles from Macomb County, Michigan

\begin{tabular}{llllll}
\hline Sample & PFOS & PFOSA & PFOA & PFHS & Remarks (sex, location, age, weight) \\
\hline Mink $(\mathrm{n}=7)$ & $18000(1280-59,500)$ & $103(<2-181)$ & $<2-3.33^{*}$ & $21(7.5-40)$ & $\begin{array}{c}\text { Male, Kalamazoo River watershed, } \\
\text { age 0.5-3 yrs, 0.7-1.1 kg }\end{array}$ \\
Mink $(\mathrm{n}=1)$ & 41 & $<2$ & 12.2 & 6.3 & $\begin{array}{c}\text { Female, Kalamazoo River watershed } \\
\text { Green frog }(\mathrm{n}=2)\end{array}$ \\
Green frog $(\mathrm{n}=2)$ & $168(50-285)$ & $<19$ & $<72$ & $<6$ & Adult, Calkin's dam \\
Snapping turtle $(\mathrm{n}=2)$ & $137(105-169)$ & $<19$ & $<72$ & $<6$ & Adult, 118 th pond and Swan Creek \\
Snapping turtle $(\mathrm{n}=3)$ & $6.13(<1-8.8)$ & $<1$ & $<2.5$ & $<1$ & Adult male, $8.9-9.2 \mathrm{~kg}$ \\
\hline
\end{tabular}

Note: Values below the detection limit were not included in the means (in parentheses).

${ }^{\text {a }}$ Only one detectable observation.

For abbreviation, see Table 1.

mouth bass were similar (4.1 and $4.5 \mathrm{ng} / \mathrm{g}$, wet weight, respectively) in samples collected from the Calumet River. The apparent lack of biomagnification of PFOS from round goby to smallmouth bass could be due to the fact that the whole body was analyzed for round gobies, whereas only muscle tissue was analyzed for smallmouth bass. Therefore, the comparison of PFOS concentrations between these two species is not direct. Because PFOS binds to proteins (rather than lipids) and accumulates in liver and blood, a whole-body analysis would be needed to estimate biomagnification potential in higher trophic-level organisms. However, analysis of whole body would be a daunting task for large animals such as salmonid fishes, mink, and predatory birds.

Because perfluorinated compounds preferentially accumulate in livers, this tissue was analyzed from Chinook salmon and lake whitefish collected from Michigan waters. The concentrations of PFOS in livers of these predatory fish were compared with those of prey species such as zebra mussels, round gobies, and amphipods (Table 2). Livers of Chinook salmon collected from the Grand River contained an average PFOS concentration of $100 \mathrm{ng} / \mathrm{g}$, wet weight, a level approximately 10- to 20-fold greater than that found for round gobies. The mean concentration of PFOS in livers of lake whitefish (67 ng/g, wet weight) collected from Thunder Bay, Lake Huron was 6- to 8-fold greater than that found for round gobies, and 10- to 20-fold greater than those found in zebra mussels and amphipods. The diet of lake whitefish includes zebra mussels and insect larvae, whereas the diet of Chinook salmon includes small fishes such as minnows, alewife, and smelt (Rybicki and Clapp 1996). Carp from Saginaw Bay contained concentrations of PFOS as great as $297 \mathrm{ng} / \mathrm{g}$, wet weight, in muscle tissue (Table 2). Carp feed primarily on zebra mussels and trout eggs (Marsden 1997). Also, relatively high concentrations of PFOS were found in the eggs of fish (Table 2). Concentrations in eggs were higher than those found in the livers of lake whitefish. This suggests preferential binding of PFOS to egg albumin, and transfer of this compound to the eggs. Thus, in oviparous organisms, females may excrete considerable burdens of perfluorinated compounds via egg laying. Early life stages of organisms are vulnerable to the effects of chemical exposures. Occurrence of great concentrations of PFOS in eggs suggests exposure of the young developing from these eggs. Great concentrations of PFOS have been reported to occur in the eggs of fish-eating water birds (Giesy and Kannan 2001; Rattner et al. 2004).

It is also worth that PFOSA was found in several lower trophic-level organisms including zebra mussel and round gobies. However, PFOSA was not found in the livers of higher trophic-level fish such as Chinook salmon. PFOSA is an intermediate metabolite during the transformation of precursor molecules such as n-ethyl perfluorooctanesulfonamidoethanol or n-methyl perfluorooctanesulfonamidoethanol, which are used as surfactants in a variety of products. Transformation of n-ethyl perfluorooctanesulfonamide to PFOS and PFOSA by rainbow trout microsomes has been reported (Tomy et al. 2004).

High concentrations of PFOS were found in the livers of mink collected from the Kalamazoo River watershed (Table 3). A concentration of 59,500 ng/g, wet weight, was found in the liver of an adult male mink. This is the highest concentration reported for PFOS in any aquatic organism studied thus far. Concentrations of PFOS in mink from the Kalamazoo River watershed were 10 to 20 times greater than those in the livers of mink from Illinois and Massachusetts, USA (Kannan et al. 2002c). The mean concentration of PFOS in liver from male mink was $18,000 \mathrm{ng} / \mathrm{g}$, wet weight. This 
Table 4. Concentrations of PFOS, PFOSA, PFOA, and PFHS (ng/g, wet wt) in various tissues of bald eagles collected from Upper Peninsula of Michigan in 2000, USA

\begin{tabular}{|c|c|c|c|c|c|c|}
\hline Eagle no. & Tissue & PFOS & PFOSA & PFOA & PFHS & Remarks (sex, location, cause of death) \\
\hline \multirow[t]{4}{*}{ Bald eagle 1 (373) } & Liver & 1740 & $<75$ & $<19$ & $<19$ & \multirow[t]{4}{*}{ Adult male, Cecil Bay, died of bacterial infection } \\
\hline & Kidney & 1480 & $<75$ & $<38$ & $<19$ & \\
\hline & Gall bladder & 1490 & $<75$ & $<38$ & $<19$ & \\
\hline & Muscle & 96.2 & $<75$ & $<38$ & $<19$ & \\
\hline \multirow[t]{2}{*}{ Bald eagle 2 (374) } & Liver & 394 & $<75$ & $<19$ & $<19$ & \multirow[t]{2}{*}{ Adult male, Ironwood, died of trauma } \\
\hline & Testes & 183 & $<75$ & $<38$ & $<19$ & \\
\hline \multirow[t]{2}{*}{ Bald eagle 3 (377) } & Muscle & 79.3 & $<75$ & $<38$ & $<19$ & \multirow[t]{2}{*}{ Juvenile female, Mackinac, peritonitis } \\
\hline & Kidney & 446 & $<75$ & $<38$ & $<19$ & \\
\hline \multirow[t]{4}{*}{ Bald eagle 4 (378) } & Muscle & $<7.5$ & $<75$ & $<38$ & $<19$ & \multirow[t]{4}{*}{ Juvenile female, Menominee County, trauma } \\
\hline & Liver & 75.4 & $<75$ & $<19$ & $<19$ & \\
\hline & Kidney & 74.6 & $<75$ & $<38$ & $<19$ & \\
\hline & Ovary & 68.0 & $<75$ & $<38$ & $<19$ & \\
\hline \multirow[t]{2}{*}{ Bald eagle 5 (379) } & Muscle & 13.9 & $<75$ & $<38$ & $<19$ & \multirow[t]{2}{*}{ Adult female, Paint River, trauma } \\
\hline & Liver & 79.1 & $<75$ & $<19$ & $<19$ & \\
\hline \multirow[t]{3}{*}{ Bald eagle 6 (381) } & Muscle & $<7.5$ & $<75$ & $<38$ & $<19$ & \multirow[t]{3}{*}{ Adult male, Fence River, trauma } \\
\hline & Liver & 26.5 & $<38$ & $<38$ & $<38$ & \\
\hline & Kidney & 35 & $<75$ & $<38$ & $<19$ & \\
\hline \multirow[t]{2}{*}{ Bald eagle 7 (382) } & Muscle & $<7.5$ & $<75$ & $<38$ & $<19$ & \multirow[t]{2}{*}{ Juvenile female, Kallio, trauma } \\
\hline & Liver & 47.2 & $<38$ & $<19$ & $<38$ & \\
\hline
\end{tabular}

For abbreviation, see Table 1.

value is 100 times greater than those measured in fish or other aquatic benthic organisms analyzed. Prey items of mink include small mammals such as shrews, muskrats, fish (such as crayfish, carp, smallmouth bass), and turtles. PFOSA, PFOA, and PFHS were also found in the livers of mink. However, concentrations of these compounds were two to three orders of magnitude less than the concentrations of PFOS. Water samples collected from several locations in the Kalamazoo River also contained PFOS concentrations 5- to 10-fold greater than those from the Raisin and St. Clair Rivers in Michigan (Sinclair et al. 2004). Concentrations of PFOS in livers of mink were $1 \times 10^{6}$ fold greater than the concentrations measured from water from the Kalazamoo River $(17 \mathrm{ng} / \mathrm{L}$, Sinclair et al. 2004). A PFOS concentration as high as $285 \mathrm{ng} / \mathrm{g}$, wet weight, was found in the livers of frogs collected from the Kalamazoo River. The occurrence of high concentrations of PFOS in mink from the Kalamazoo River suggests the presence of local sources of this compound.

Blood plasma of snapping turtles collected from Macomb County near Lake St. Clair contained considerable concentrations of PFOS (Table 3). PFOS concentrations ranging from 105 to $169 \mathrm{ng} / \mathrm{mL}$ (mean: $137 \mathrm{ng} / \mathrm{mL}$ ) in males and from <1 to $8.8 \mathrm{ng} / \mathrm{mL}$ (mean: $6.13 \mathrm{ng} / \mathrm{mL}$ ) in females were found. This considerable gender difference in the concentrations of PFOS in snapping turtles suggests oviparous transfer of PFOS via egg laying, similar to that observed for fish. As mentioned earlier, all of the female turtles collected in the study were adults, and necropsy revealed the presence of large mass of eggs.

PFOS was also found in the tissues of bald eagles collected from the Upper Peninsula of Michigan (Table 4). Occurrence of PFOS in ovaries, testes, kidneys, and muscle suggests perfusion of this compound in various body tissues. Earlier studies reported the occurrence of PFOS in brain tissues of laboratory-exposed rats (Austin et al. 2003). In bald eagles, liver contained the greatest concentration of PFOS, although concentrations in kidneys were almost as high as those found in the livers. The highest concentration of PFOS, $1740 \mathrm{ng} / \mathrm{g}$, wet weight, in the liver of an adult male bald eagle was approximately 10 - to 20 -fold greater than those found in the livers of Chinook salmon or muscle of carp analyzed in this study. The mean concentration of PFOS in the livers of bald eagles was $400 \mathrm{ng} / \mathrm{g}$, wet weight, which is four- to fivefold greater than the concentrations found in several higher trophiclevel fish analyzed in this study. In addition to livers, blood plasma from nestling bald eagles also contained great concentrations of PFOS (Kannan et al. 2001a). A PFOS concentration as high as $2220 \mathrm{ng} / \mathrm{mL}$ has been reported in the plasma of bald eagles from Wisconsin, USA (Kannan et al. 2001a). A sample of gallbladder of an adult male bald eagle also contained a PFOS concentration similar to that found in the liver. PFOS has been reported to accumulate in gallbladder, similarly to bile salts, and to undergo enterohepatic circulation (Johnson et al. 1984), due to its structural similarity to bile acids containing both lipophilic and hydrophilic regions.

Assuming that PFOS concentrations measured in gallbladder reflect the concentrations in bile, biliary excretion of PFOS can be estimated. The biliary excretion rate can be calculated as:

$$
\begin{aligned}
\text { Biliary excretion rate }(\% \text { per day })= & {[\text { Amount in bile }(\mu \mathrm{g})} \\
& \div \operatorname{Amount} \text { in } \operatorname{body}(\mu \mathrm{g})] \\
& * 100
\end{aligned}
$$

For this estimation, data for muscle, liver, and gallbladder from a single individual were used (no. 373; Table 4). The excretion rate was calculated on the basis of the amount (burden) of PFOS in liver, kidney, muscle, and blood, and the amount (burden) in bile/gallbladder. The body weight of the eagle was $3.5 \mathrm{~kg}$. It was assumed that liver, kidney, and blood account for $4 \%$ each of the total body mass and that muscle tissue accounts for $30 \%$ of the body mass. The PFOS con- 
centration in blood was assumed to be similar to that in the liver. Daily bile excretion was assumed to be $10 \mathrm{~g}$. Based on the concentrations of PFOS found in liver, kidney, blood, and muscle, the total body burden of PFOS in this eagle was estimated to be $800 \mu \mathrm{g}$. The burden of PFOS in bile was 14.9 $\mu \mathrm{g}$. Based on these figures, the excretion rate of PFOS was estimated to be $1.9 \%$ per day, which is approximately two to three orders of magnitude greater than the rates estimated for persistent organochlorine pollutants such as PCBs and DDT (Senthilkumar et al. 2002). This result may suggest that PFOS is excreted relatively rapidly from the body. However, unlike persistent organochlorine pollutants, binding of perfluorinated compounds to proteins and retention by enterohepatic circulation are the major factors that determine accumulation and retention in biota.

In summary, these results suggest the occurrence of PFOS in lower trophic-level benthic invertebrates of a Great Lakes food chain. Concentrations of PFOS in benthic invertebrates and also in round gobies were 1000-fold greater than those in surrounding water. PFOS tends to biomagnify in higher trophiclevel fish such as salmonids. A BMF of 10-20 was determined between round gobies and Chinook salmon liver. Concentrations of PFOS were the greatest in mink and bald eagles. A BMF of 5-10 was observed between salmon liver and eagle/ mink livers. Based on the fact that higher trophic-level organisms have greater capacity to metabolize environmental contaminants than do lower trophic-level organisms, precursor compounds (e.g., n-ethyl/n-methyl perfluorooctanesulfonamidoethanol) of PFOS that are present in lower trophic-level organisms as unmetabolized or partially metabolized molecules serve as a contributory source of PFOS for higher trophic-level organisms. This may be a source of error in the estimation of BMF in this study. Further studies are needed to evaluate the occurrence and metabolism of precursor compounds of PFOS and other related fluorinated compounds in aquatic organisms.

Acknowledgments. This study was supported in part by a grant from the 3 M Company, St. Paul, MN. The authors wish to thank Martin B. Berg, Loyola University, Chicago, for assistance with sampling benthic organisms.

\section{References}

Austin ME, Kasturi BS, Barber M, Kannan K, Mohankumar PS, Mohankumar SMJ (2003) Neuroendocrine effects of perfluorooctane sulfonate in rats. Environ Health Perspect 111:14851489

Bruner KA, Fisher SW, Landrum PF (1994) The role of the zebra mussels, Dreissena polymorpha, in contaminant cycling: 1 . The effect of body size and lipid content on the bioconcentration of PCBs and PAHs. J Great Lakes Res 20:725-734

Giesy JP, Kannan K (2001) Global distribution of perfluorooctane sulfonate and related perfluorinated compounds in wildlife. Environ Sci Technol 35:1339-1342

Giesy JP, Kannan K (2002) Perfluorochemicals in the environment. Environ Sci Technol 36:147A-152A

Hanari N, Kannan K, Horii Y, Taniyasu S, Yamashita N, Jude DJ, Berg MB (2004) Polychlorinated naphthalenes and polychlorinated biphenyls in benthic organisms of a Great Lakes food chain. Arch Environ Contam Toxicol 47:84-93
Hansen KJ, Clemen LA, Ellefson ME, Johnson HO (2001) Compound-specific, quantitative characterization of organic fluorochemicals in biological matrices. Environ Sci Technol 35:766770

Hansen KJ, Johnson HO, Eldridge JS, Butenhoff JL, Dick LA (2002) Quantitative characterization of trace levels of PFOS and PFOA in the Tennessee River. Environ Sci Technol 36:1681-1685

Johnson JD, Gibson SJ, Ober RF (1984) Cholestyramine-enhanced fecal elimination of carbon-14 in rats after administration of ammonium [14C] perfluorooctanoate or potassium [14C]perfluorooctanesulfonate. Fund Appl Toxicol 4:972-976

Jude DJ, Janssen J, Crawford G (1995) Ecology, distribution, and impact of the newly introduced round and tubenose gobies on the biota of the St. Clair and Detroit Rivers. In: Munawar M, Edsall T, Leach J (eds) The Lake Huron ecosystem: ecology, fisheries and managementEcovision World Monograph SeriesAmsterdam, The Netherlands pp 447-460

Kannan K, Hansen SP, Franson CJ, Bowerman WW, Hansen KJ, Jones PD, Giesy JP (2001a) Perfluorooctane sulfonate in fisheating water birds including bald eagles and albatrosses. Environ Sci Technol 35:3065-3070

Kannan K, Koistinen J, Beckmen K, Evans T, Gorzelany J, Hansen KJ, Jones PD, Giesy JP (2001b) Accumulation of perfluorooctane sulfonate in marine mammals. Environ Sci Technol 35:1593-1598

Kannan K, Hansen KJ, Wade TL, Giesy JP (2002a) Perfluorooctane sulfonate in oysters, Crassostrea virginica, from the Gulf of Mexico and Chesapeake Bay, USA. Arch Environ Contam Toxicol 42:313-318

Kannan K, Corsolini S, Falandysz J, Oehme G, Focardi S, Giesy JP (2002b) Perfluorooctane sulfonate and related fluorinated hydrocarbons in marine mammals, fish and birds from coasts of the Baltic and the Mediterranean Seas. Environ Sci Technol 36:3210-3216

Kannan K, Newsted J, Halbrook RS, Giesy JP (2002c) Perfluorooctane sulfonate and related fluorinated hydrocarbons in mink and river otters from the United States. Environ Sci Technol 36:2566-2571

Kannan K, Choi J-W, Iseki N, Senthilkumar K, Kim DH, Masunaga S, Giesy JP (2002d) Concentrations of perfluorinated acids in livers of birds from Japan and Korea. Chemosphere 49:225-231

Martin GW, Corkum LD (1994) Predation of zebra mussels by crayfish. Can J Zool 72:1867-1871

Martin JW, Mabury SA, Solomon KR, Muir DCG (2003) Bioconcentration and tissue distribution of perfluorinated acids in rainbow trout (Oncorhynchus mykiss). Environ Toxicol Chem 22: 196-204

Martin JW, Smithwick MM, Braune BM, Hoekstra PF, Muir DCG, Mabury SA (2004) Identification of long-chain perfluorinated acids in biota from the Canadian Arctic. Environ Sci Technol 38:373-380

Marsden JE (1997) Common carp diet includes zebra mussels and lake trout eggs. J Freshw Ecol 12:491-492

Moody CA, Martin JW, Kwan WC, Muir DCG, Mabury SA (2002) Monitoring perfluorinated surfactants in biota and surface water samples following an accidental release of fire-fighting foam into Etobicoke creek. Environ Sci Technol 36:545-551

Rattner BA, McGowan PC, Golden NH, Hatfield JS, Toschik PC, Lukei RF Jr, Hale RC, Schmitz-Afonso I, Rice CP (2004) Contaminant exposure and reproductive success of ospreys (Pandion haliaetus) nesting in Chesapeake Bay regions of concern. Arch Environ Contam Toxicol 47:126-140

Rybicki RW, Clapp DF (1996) Diet of Chinook salmon in eastern Lake Michigan, 1991-1993. Fisheries Division research report no. 2027 Michigan Department of Natural Resources, Cherlevoix, Michigan, 22

Saito N, Saski K, Nakatome K, Harada K, Yoshinaga T, Koizumi A (2003) Perfluoroctanesulfonate concentrations in surface water in Japan. Arch Environ Contam Toxicol 45:149-158 
Savitz J, Bardygulla LG, Scoma L (1996) Fish species in Chicago harbors of Lake Michigan, 1988 to 1990, as determined by electroshocking and creel surveys. J Freshw Ecol 11:469-474

Schultz MM, Barofsky DF, Field JA (2004) Quantitative determination of fluorotelomer sulfonates in groundwater by LC MS/MS. Environ Sci Technol 38:1828-1835

Senthilkumar K, Kannan K, Giesy JP, Masunaga S (2002) Distribution and elimination of polychlorinated dibenzo- $p$-dioxins, dibenzofurans, biphenyls, and $p, p^{\prime}$-DDE in tissues of bald eagles from the Upper Peninsula of Michigan. Environ Sci Technol 36:2789-2796

Sinclair E, Taniyasu S, Yamashita N, Kannan K (2004) Perfluorooctanoic acid and perfluorooctane sulfonate in Michigan and New York waters. Organohalogen Compounds 67:4069-4073

Stock NL, Lau FK, Ellis DA, Martin JW, Muir DCG, Mabury SA (2004) Polyfluorinated telomere alcohols and sulfonamides in the North American troposphere. Environ Sci Technol 38:991-996
Taniyasu S, Kannan K, Horii Y, Hanari N, Yamashita N (2003) A survey of perfluorooctane sulfonate and related perfluorinated organic compounds in water, fish, birds and humans from Japan. Environ Sci Technol 37:2634-2639

Tomy GT, Tittlemier SA, Palace VP, Budakowski WR, Braekevelt E, Brinkworth L, Friesen K (2004) Biotransformation of N-ethyl perfluorooctanesulfonamide by rainbow trout (Oncorhynchus mykiss) liver microsomes. Environ Sci Technol 38:758-762

Van de Vijver KI, Hoff PT, Das K, Van Dongen W, Esmans EL, Jauniaux T, Bouquegneau JM, Blust R, De Coen W (2003) Perfluorinated chemicals infiltrate ocean waters: link between exposure levels and stable isotope ratios in marine mammals. Environ Sci Technol 37:5545-5550

Yamashita N, Kannan K, Taniyasu S, Horii Y, Okazawa T, Petrick G, Gamo T (2004) Analysis of perfluorinated acids at parts-perquadrillion levels in seawater using liquid chromatography-tandem mass spectrometry. Environ Sci Technol 38:5522-5528 